\title{
Penalaran Berbasis Kasus Untuk Diagnosis Penyakit Malaria Dengan Menggunakan Metode Minkowsky Distance
}

\author{
Abdul Mubarak ${ }^{1}$, Munazat Salmin², Achmad Fuad ${ }^{3}$, Saiful Do Abdullah ${ }^{4}$ \\ Fakultas Teknik, Program Studi Teknik Informatika \\ Universitas Khairun Ternate \\ munazatc28@gmail.com
}

\begin{abstract}
Abstrak
Kota Ternate merupakan salah satu kota yang berada di Propinsi Maluku Utara, dimana menjadi salah satu kota endemis Malaria. Penyakit malaria merupaka penyakit endemic yang artinya setiap tahun pasti ada penderita malaria. Perkembangan teknologi informasi sangat banyak membantu kerja-kerja manusia baik itu dalam dunia medis maupun yang lain. Penalaran Berbasis Kasus adalah bagian dari kecerdasan buatan yang mana menyelesaikan suatu kasus baru berdasarkan pengalaman-pengalam sebelumnya, jadi ketika kita terapkan dalam dunia medis akan memudahkan para dokter dalam pengambilan keputusan. Tujuan dari penelitian ini adalah untuk membangun system dengan Case Based Reasoning (Penalaran Berbasis Kasus) dalam mendiagnosis penyakit Malaria. Hasil yang diharapkan dari penelitian ini yaitu 1). Dapat membantu tenaga medis dalam mengambil keputusan tentang diagnosis penyakit Malaria. 2). Mengetahui seberapa besar tingkat akurasi Minkowski Distance untuk kasus diagnosis penyakit Malaria. Mengetahui seberapa besar tingkat akurasi Minkowski Distance untuk kasus diagnosis penyakit Malaria. Pada penelitian ini data rekam medik sebanyak 83 Pasien, dimana data latih sebanyak 58 kasus dan data uji sebanyak 25 kasus. Setelah melakukan pengujian maka didapatkan akurasi system sebanyak $92 \%$.
\end{abstract}

\section{Kata kunci: Penalaran Berbasis Kasus, Minkowski Distance, Malaria}

\begin{abstract}
Ternate City is one of North Maluku Province, one of the malaria-endemic cities. Malaria is an endemic disease, which means that there must be malaria sufferers every year. The development of information technology is very much helping human work, both in the medical world and others. Case-Based Reasoning is part of artificial intelligence that solves a new case based on previous experiences, so applying it in the medical world will make it easier for doctors to make decisions. This research aims to build a system with Case-Based Reasoning in diagnosing Malaria. The expected results of this study are 1). Can assist medical personnel in making decisions about the diagnosis of Malaria. 2). Knowing how much accuracy the Minkowski Distance is for diagnosing cases of Malaria. Knowing how much accuracy the Minkowski Distance is for diagnosing cases of Malaria. In this study, the medical record data were 83 patients, where the training data were 58 cases, and the test data were 25 cases. After testing, the system accuracy is obtained as much as $92 \%$.
\end{abstract}

Keywords: Case-Based Reasoning, Minkowski Distance, Malaria.

\section{PENDAHULUAN}

Kota Ternate merupakan salah satu kota yang paling maju di Propinsi Maluku Utara dengan jumlah penduduk 218 ribu jiwa. [1]. Sebagai kota yang berada di Propinsi Maluku Utara, Kota Ternate merupakan salah satu kota yang masuk dalam kategori endemis penyakit Malaria 
sebagaimana dijelaskan oleh Menteri Kesehatan Republik Indonesia Prof. dr. Nila Djuwita F. Moeloek, saat menghadiri acara Jambore Malaria Nasional ke-10 serta Jambore Fasilitator PLA Malaria ke-3 di Kota Ternate yang dilaksanakan di Pelabuhan Perikanan pada tanggal 27 april 2017.

Malaria merupakan penyakit menular yang disebabkan oleh plasmodium, yaitu makhluk hidup bersel satu yang termasuk dalam kelompok Protozoa. Malaria ditularkan melalui gigitan nyamuk Anopheles betina yang mengandung Plasmodium di dalamnya.

Penyakit malaria masih termasuk dalam penyakit endemik yang diderita oleh masyarakat kota ternate, semakin banyak pasien penyakit malaria maka tentu saja semakin banyak dokter yang dibutuhkan/bekerja untuk diagnosis pasien. Perkembangan teknologi informasi akan sangat membantu kerja-kerja dokter terutama dari sisi diagnosis penyakit, kecerdasan buatan salah satu solusi dalam membantu dokter dalam mendukung pengambilan keputusanan untuk diagnosis penyakit tertentu.

Kecerdasan buatan yang saat ini yang sangat familiar untuk menyelesaiakan kasus-kasus yang berkaitan dengan medis diantaranya case based reasoning ( penalaran berbasis kasus). Penalaran berbasis kasus merupakan sebuah sistem perangkat lunak yang bekerja dengan mengukur tingkat kemiripan dari kasus baru dengan kasus lama yang tersimpan pada case based. Proses mencari kemiripan antara kasus baru dengan kasus lama disebut proses retrieval. Salah satu metode yang digunakan dalam mengukur kimiripan antara kasus tersebut adalah minkowski distance.
Minkowski distance adalah metode perhitungan jarak yang sanagat banyak digunakan untuk mencari similaritas pada suatu kasus dimana semakin dekat jarak antara kasus baru dan lama dengan toleransi 80\% maka menunjukan bahwa dua kasus tersebut similar.

Saat ini untuk mendiagnosis penyakit malaria masih berpatokan pada dokter spesialis penyakit malaria. Berdasarkan uraian diatas maka perlu melakukan penelitian tentang Penalaran berbasis kasus untuk Diagnosis Penyakit Malaria Menggunakan Metode Minkowski Distance.

\section{LANDASAN TEORI}

\section{Penyakit Malaria}

Malaria adalah penyakit menular yang disebabkan plasmodium yaitu makhluk hidup bersel satu yang termasuk dalam kelompok protozoa. Malaria ditularkan melalui gigitan nyamuk Anopheles betina yang mengandung Plasmodium di dalamnya. Plasmodium yang terbawa melalui gigitan nyamuk akan hidup dan berkembang biak dalam sel darah merah manusia. Penyakit ini menyerang semua kelompok umur baik laki - laki maupun perempuan. Orang - orang yang terkena malaria akan memiliki gejala: demam, menggigil, berkeringat, sakit kepala, mual dan muntah. [2]

Persebaran endemis Malaria di Indonesia dapat dilihat pada gambar 2.1 dimana, Propinsi Maluku Utara menempati posisi 5 teratas setelah Papua, Papua Barat, NTT, dan Maluku. 


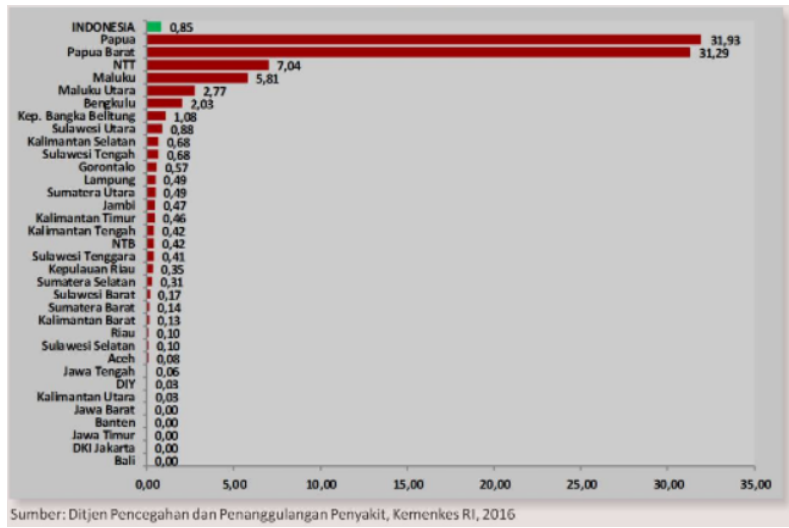

Gambar 1 Sebaran kasus Malaria di Indonesia.

\section{Gejala Penyakit dan Faktor Resiko Penyakit Malaria}

Terdapat 16 Gejala dan 2 Faktor Resiko Penyakit Malaria dengan kode gejala dan kode faktor resiko dapat anda lihat dengan 3 Jenis Penyakit Malaria.

Tabel 1 Jenis Penyakit Malaria

\begin{tabular}{|c|c|c|}
\hline No & Kode Penyakit & Nama Penyakit \\
\hline 1 & B50.0 & $\begin{array}{c}\text { Malaria } \\
\text { Falciparum }\end{array}$ \\
\hline 2 & B51.0 & Malaria Vivax \\
\hline 3 & B54 & $\begin{array}{c}\text { Malaria } \\
\text { Malariae }\end{array}$ \\
\hline
\end{tabular}

Penalaran Berbasis Kasus

Istilah penalaran berbasis kasus mulai banyak dikenal diberbagai bidang baik dalam bidang teknologi informasi dan ilmu komputer. Penalaran berbasis kasus adalah pendekatan pemecahan masalah berdasarkan membandingkan kasus-kasus baru terjadi dengan pengalaman masa lalu atau kasus sebelumnya [3]

\section{Siklus Penalaran Berbasis Kasus}

Siklus Penalaran berbasis kasus meliputi: Retrieval, Reuse, Revise dan Retain. Retrieval, mencari kasus terdahulu yang serupa (similar) dengan kasus baru. Untuk lebih jelas tentang tahapan proses pada CBR dapat dilihat pada Gambar 2.

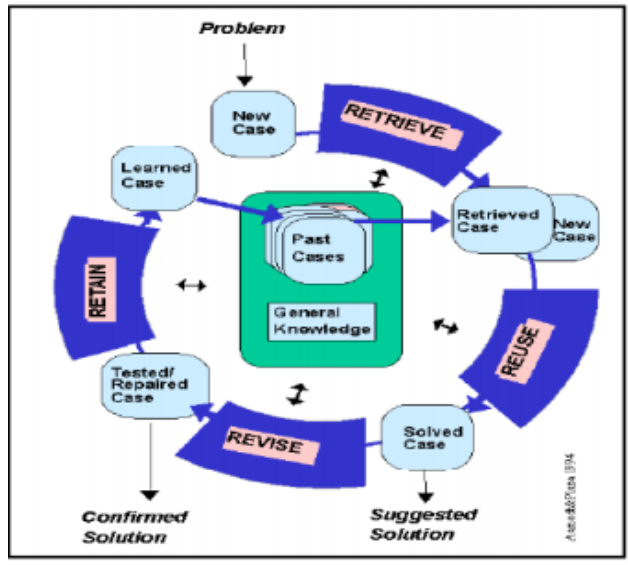

Gambar 2. CBR [4]

Pada Gambar 2 Siklus penalaran berbasis kasus yaitu kasus baru dicocokkan dengan kasus-kasus yang ada di dalam basis data penyimpanan kasus dan menemukan satu atau lebih kasus yang mirip (retrieval). Solusi yang dianjurkan melalui pencocokan kasus kemudian digunakan kembali (reuse) untuk kasus yang serupa, solusi yang ditawarkan mungkin dapat dirubah dan diadopsi (revise). Jika kasus baru tidak ada yang cocok di dalam database penyimpanan kasus, maka CBR akan menyimpan kasus baru tersebut (retain) di dalam database pengetahuan

\section{Data Flow Diagram (DFD)}

Data Flow Diagram (DFD) merupakan gambaran grafis dari suatu sistem yang menggunakan sejumlah bentuk-bentuk simbol untuk menggambarkan cara data mengalir melalui suatu proses yang berkaitan [5]

\section{Diagram Konteks}

Diagram konteks merupakan level tertinggi dari DFD yang terdiri dari suatu proses yang menggambarkan suatu sistem terkait dengan dokumen output dan input serta entitas yang berhubungan dengan sistem. Sistem CBR diagnosis penyakit 
Malaria ini berhubungan dengan dua entitas, yaitu pakar dan paramedis.

\section{RELASI ANTAR TABEL}

Relasi antara tabel digunakan untuk memudahkan proses pembuatan sistem case base reasoning dimana setiap tabel yang terdiri dari primary key dan forign key memiliki keterkaitan satu dengan yang lain pada tabel.

\section{REPRESENTASI KASUS}

Fitur yang dipilih berdasarkan dua pertimbangan yakni tingkat kepentingan fitur terhadap diagnosis jenis penyakit malaria dan ketersediaan fitur tersebut dalam catatan rekam medik. Berdasarkan dua pertimbangan tersebut, maka ditentukan fitur-fitur yang dianggap mewakili dalam melakukan diagnosis penyakit malaria diantaranya usia, jenis kelamin, gejala dan faktor resiko Pasien penyakit malaria.

\section{PENGUKURUN SIMILARITAS}

Pengukuran kemiripan (similarity) dilakukan dengan membandingkan fitur yang ada pada kasus dengan fitur sejenis yang ada pada basis kasus. Suatu kasus dikatakan mirip dengan kasus lain apabila nilai similaritasnya mendekati 1 dan jika nilai similaritasnya sama dengan 1 maka suatu kasus tersebut identik.

\section{Similaritas Lokal}

Similaritas lokal menunjukan kemiripan antara atribut permasalahan terhadap atribut yang sama dari satu kasus. Dengan asumsi bahwa semua kasus yang ada dalam basis kasus memiliki fitur yang bernilai (sudah diseleksi) ada fitur target yang sudah diketahui nilainya dan fitur target yang belum diketahui nilainya.
1. Fitur target yang sudah diketahui nilainya Terdapat tiga tipe data fitur yaitu:

\section{a. Data numerik}

Berlaku fungsi similaritas lokal [6]

$$
f_{k}\left(S_{k}, T_{k}\right)=1-\frac{\left|S_{k}-T_{k}\right|}{R}
$$

$$
\begin{array}{ll}
\text { Keterangan } & : \\
f_{k}\left(S_{k}, T_{k}\right) & : \text { similaritas lokal } \\
& \text { fitur ke- } k \text { antara } \\
& \text { source case dan } \\
& \text { fitur target case. } \\
S_{k} & : \text { fitur ke- } k \text { dari } \\
& \text { source case. } \\
T_{k} & : \text { fitur ke- } k \text { dari target } \\
& \text { case. } \\
R & : \text { Range nilai untuk }
\end{array}
$$

fitur tersebut.

\section{Data Boolean}

Berlaku fungsi similaritas lokal [6]

$$
\begin{aligned}
& f k\left(S_{k}, T_{k}\right)=\left\{\begin{array}{l}
1 \text { jika } S_{k}=T_{k} \\
\text { lainnya }
\end{array}\right. \\
& \text { untuk } S_{k}, T_{k}\{\text { benar,salah }\}
\end{aligned}
$$

\section{Data simbolik}

Nilai similaritas sesuai dengan tabel bobot kedekatan fitur yang disusun oleh pakar.

Fitur yang tidak diketahui nilainya

Pengukuran similaritas dilakukan dengan mengabaikan fitur yang tidak diketahui nilainya atau mengganti dengan nilai $0 . \quad$ Kemudian dihitung similaritasnyanya (lokal dan global).

Pengukuran Tingkat Keyakinan

Mengemukakan untuk menghitung tingkat keyakinan bahwa suatu permasalahan $T$ merupakan bagian dari sebuah kelas kasus $S$. Pengukuran tingkat keyakinan yang 
digunakan dalam penelitian ini mencakup dua hal [4]

\section{Tingkat keyakinan pakar}

Tingkat keyakinan pakar merupakan kepastian diagnosis dari pakar berdasarkan gejala dan faktor resiko yang dialami pasien. Tingkat keyakinan pakar diberikan nilai antara $50 \%$ sampai $100 \%$ yang ditentukan oleh pakar. Semakin tinggi keyakinan pakar maka semakin tinggi kepastian terhadap hasil diagnosis suatu kasus.

\section{Tingkat keyakinan permasalahan baru}

Untuk perhitungan tingkat keyakinan pada permasalahan baru menggunakan persamaan (3) [4]

$$
P_{k}\left(S_{k}, T_{k}\right)=P_{k}\left(S_{k}\right) * \frac{J\left(S_{k}, T_{k}\right)}{J\left(T_{k}\right)}
$$

$$
\begin{aligned}
& \text { Keterangan : } \\
& P_{k}\left(S_{k}, T_{k}\right) \quad: \text { tingkat keyakinan } \\
& \text { antara kasus } \mathrm{T} \text { (target } \\
& \text { case) dan S (source } \\
& \text { case). } \\
& P_{k}\left(S_{k}\right) \quad: \text { presentase tingkat } \\
& \text { keyakinan dalam suatu } \\
& \text { kasus ke- } k \text { dalam } \\
& \text { source case. } \\
& J\left(S_{k}, T_{k}\right) \quad \text { : banyak fitur dalam } \\
& \text { target case yang } \\
& \text { muncul pada source } \\
& \text { case } \\
& J\left(T_{k}\right) \quad \text { : banyak fitur dalam } \\
& \text { target case. }
\end{aligned}
$$

\section{Similaritas Global}

Dalam penelitian ini metode yang digunakan untuk mengitung kemiripan kasus baru dengan kasus lama yaitu metode minkowski distance. Minkowski distance merupakan metode perhitungan kemiripan berdasarkan jarak. Metode ini juga merupakan generalisasi dari metode distance yang lain. Jika Jika r=1 dikenal dengan manhattan/city block distance, jika $\mathrm{r}=2$ dikenal dengan euclidean distance [7] dan jika $\mathrm{r}=$ infinity (tak hingga) dikenal dengan chebyshev distance. Rumus minkowski distance [8] seperti yang ditunjukkan pada persamaan (4).

$$
\operatorname{Sim}\left(S,\{T)=\frac{\left.\sum_{k=1}^{n}\left(w_{k}, p(s)\right)^{r} *\right)\left|f k\left(S_{k}, T_{k}\right)\right|}{\sum_{k=1}^{n}\left(w_{k}, p(s)\right)^{r}}\right.
$$

Keterangan :

Sim $(\mathrm{S}, \mathrm{T})$ : Similaritas global Antara source case (S) dan target case $(\mathrm{T})$.

$$
\begin{array}{ll}
\mathrm{n} & : \text { Banyak fitur. } \\
\mathrm{r} & : \text { Faktor minkowski (nilai } \mathrm{r}=3 \text { ) }
\end{array}
$$

$\mathrm{w}_{\mathrm{k}, \mathrm{p}(\mathrm{s})} \quad$ : Nilai bobot fitur ke-k pada source case.

$\mathrm{f}_{\mathrm{k}}\left(\mathrm{S}_{\mathrm{k}}, \mathrm{T}_{\mathrm{k}}\right) \quad$ : Fungsi similaritas lokal ke-k pada penyakit dari source case dan target case.

$\mathrm{S}_{\mathrm{k}} \quad$ : Atribut ke-k pada source

case

$\mathrm{T}_{\mathrm{k}} \quad$ : Atribut ke-k pada target case

\section{METODE PENELITIAN \\ Deskripsi Sistem}

Salah satu metode untuk menghitung similaritas pada CBR dalah minkowski distance. Metode minkowski distance digunakan dalam penelitian ini untuk mencari similaritas antar kasus.

Diagnosis untuk kasus baru (target case) memasukkan identitas pasien dan kondisi pasien berupa gejala pasien beserta faktor resikonya, kasus baru tersebut di hitung tingkat similaritas. Fitur-fitur yang digunakan adalah usia, jenis kelamin, gejala 
dan faktor resiko pasien. Fitur-fitur tersebut diberikan bobot sesuai seberapa besar pengaruhnya terhadap suatu penyakit. Pembobotan dilakukan oleh ahli dalam hal ini dokter spesialis penyakit Malaria. Kesamaan antara fitur pada kasus baru (target case) dengan fitur pada kasus lama (source case) dikalikan dengan bobot dihitung dengan menggunakan rumus similaritas lokal yaitu pada persamaan (1) dan (2), setelah mendapatkan nilai similaritas lokal akan dihitung antara kasus dengan menggunakan rumus similaritas global yaitu pada persamaan (5).

Nilai similaritas diatas threshold (80\%) yang didapatkan pada kasus kasus lama (source case) solusinya digunakan untuk kasus baru. Jika nilai similaritasnya dibawah threshold akan direvisi oleh pakar (dokter spesialis Malaria). Untuk output dari sistem case based reasoning diagnosis penyakit Malaria berupa nama jenis penyakit yang paling mirip dengan kasus baru (target case). Secara umum deskripsi sistem dapat dilihat pada Gambar 3.1.

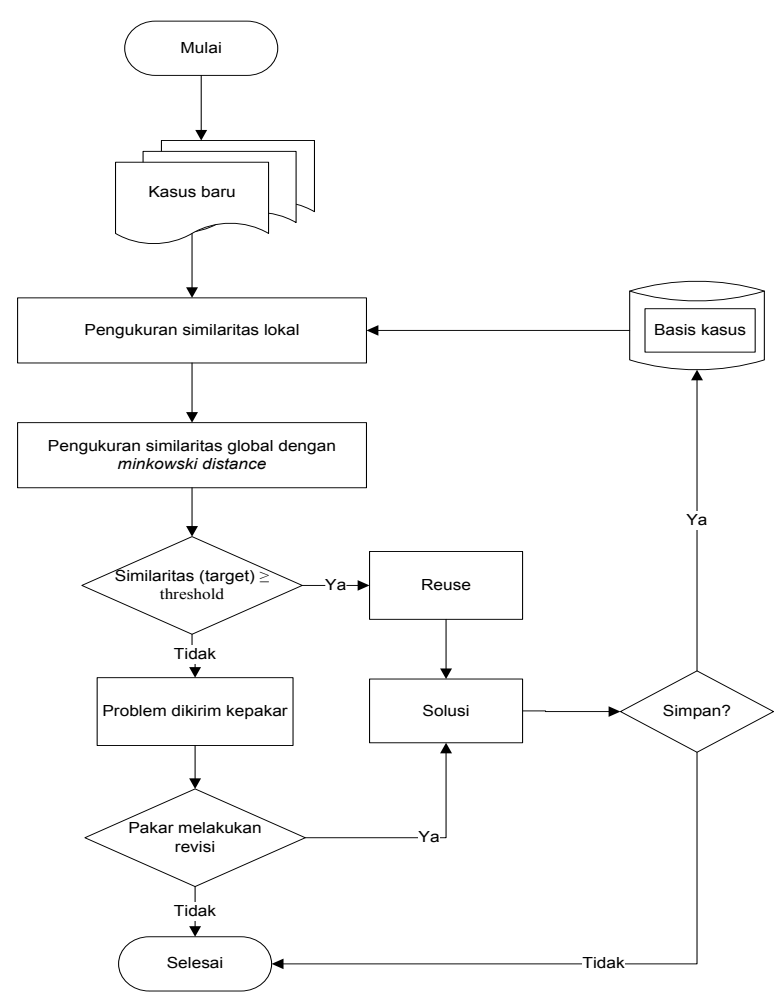

Gambar 3. Diagram Sitem CBR untuk Diagnosis Penyakit Malaria

\section{Diagram Konteks}

Diagram konteks merupakan level tertinggi dari DFD yang terdiri dari suatu proses yang menggambarkan suatu sistem terkait dengan dokumen output dan input serta entitas yang berhubungan dengan sistem. Sistem CBR diagnosis penyakit Malaria ini berhubungan dengan dua entitas, yaitu pakar dan paramedis.

1. Pakar menginput data kedalam sistem yang berupa bobot gejala, bobot faktor resiko, keyakinan pakar dan basis kasus. Pakar juga melakukan revisi terhadap kasus baru. Untuk kasus yang dilakukan revisi oleh pakar, sistem akan memberikan informasi hak akses dan notifikasi ke pakar.

2. Paramedis menginput data pasien berupa identitas pasien dan kondisi pasien (gejala dan faktor resiko yang dialami 
pasien). Sistem akan mengeluarkan hasil diagnosa ke paramedis yang melakukan diagnosa. Paramedis juga dapat menyimpan permasalahan baru ke dalam sistem. Diagram konteks pada sistem CBR diagnosa penyakit Malaria ini terlihat pada Gambar 3.2.

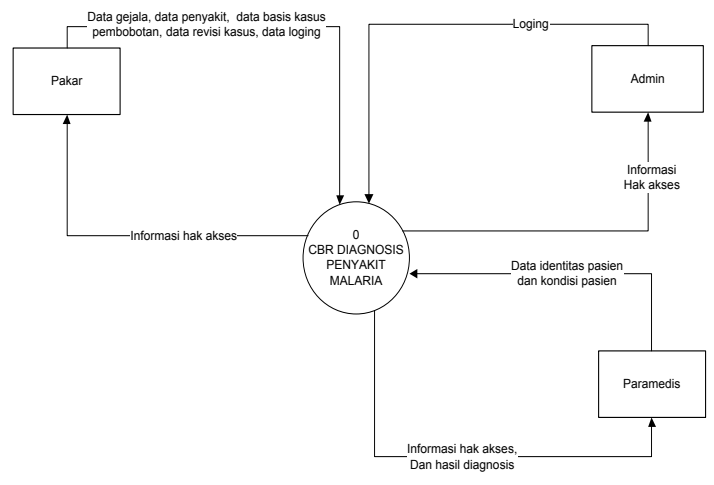

Gambar 4 Diagram konteks

Keterangan:

1. Administrator merupakan user yang memiliki level dalam pengaksesan sistem dan mengelola data user. Administrator harus melakukan login terlebih dahulu untuk menggunakan sistem.

2. Untuk masuk kesistem pakar melakukan loging terlebih dahulu. Pakar merupakan user yang memiliki hak akses terbatas. Pakar melakukan input data penyakit, input data gejala, input data faktor resiko, input data bobot, input basis kasus, dan revisi kasus.

3. Untuk masuk kesistem paramedis melakukan loging terlebih dahulu. Selain dari pakar, paramedis juga merupakan user yang memiliki hak akses terbatas. Paramedis melakukan diagnosis dan menyimpan permasalahan baru.

\section{Relasi Antar Tabel}

Tabel yang terdiri dari primary key dan forign key memiliki keterkaitan satu dengan yang lain pada tabel, misalnya tabel kasus dengan atribut id_kasus sebagai primary key berelasi dengan tabel kasus_resiko dengan tabel kasus_gejala dimana atribut id_kasus sebagai foreign key pada masing-masing tabel tersebut. Untuk lebih jelas tentang relasi antara tabel dapat disajikan pada Gambar 5.

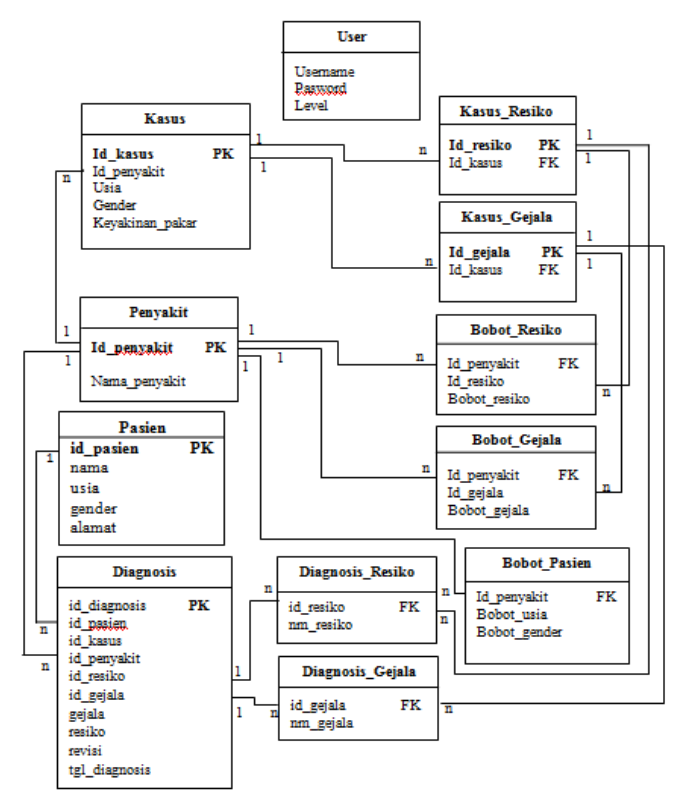

Gambar 5. Relasi Antar Tabel

\section{Metode Pengujian}

Data yang digunakan pada penelitian ini sebanyak 83 Data kasus. Terdiri dari Penyakit Malaria Falciparun 34 Kasus, Malaria Vivax 27 Kasus, dan Malaria Malariae 22 Kasus. Data tersebut akan dikelompok menjadi data uji dan data traning dimana data uji terdiri dari 25 Kasus dan Data Traning terdiri dari 58 Kasus.

\section{HASIL DAN PEMBAHASAN Menu file}

Menu file berisi sub menu login. Halaman login Pada halaman ini digunakan sebagai 
hak akses bagi user. Paramedis berhak untuk melakukan proses diagnosis pasien serta pakar dalam hal ini dokter yang berhak melakukan revisi apabila proses diagnosis dibawah nilai threshold $(0,8)$. Halaman loging seperti yang terlihat pada gambar 6 .

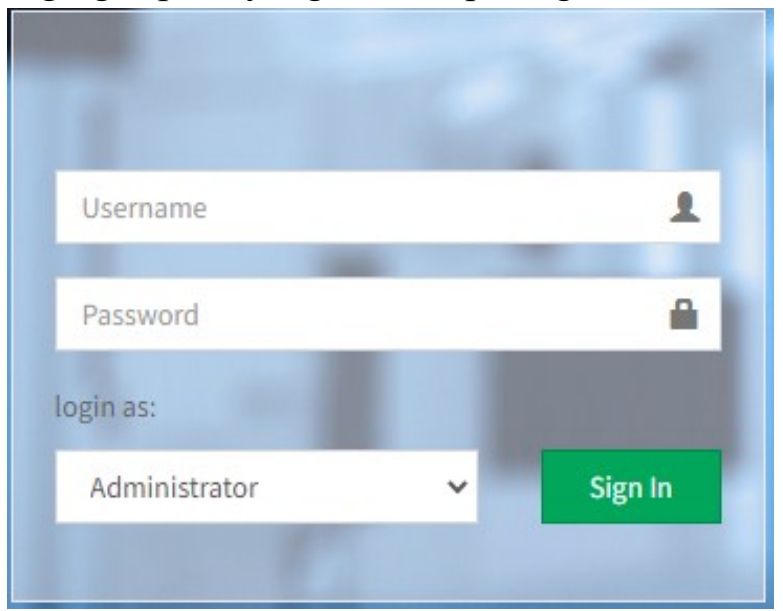

Gambar 6 Tampilan Login

\section{Menu Diagnosis}

Pada menu ini pasien diminta untuk menyampaikan keluahan berupa data pasien, gejala dan factor resiko yang di alami seperti yang di tunjukan pada gambar 7

$$
\begin{array}{|c|l|l|}
\hline \multicolumn{2}{|c|}{\text { Daftar Faktor Resiko }} & \text { Daftar Gejala } \\
\hline \# & \text { ID } & \text { Gejala } \\
\hline 1 & 601 & \text { Demam } \\
\hline 2 & 602 & \text { Demam timbul intermiten } \\
3 & 603 & \text { Demama } 2 \text { Hari } \\
\hline 4 & 604 & \text { Demam } 3 \text { hari } \\
5 & 605 & \text { Berkeringat } \\
6 & 606 & \text { Menggigil } \\
\hline
\end{array}
$$

Gambar 7. Menu Diagnosis

\section{Menu Daftar Penyakit}

Pakar dapat menggunakan fasilitas cari untuk menemukan user yang dikehendaki. Rancangan form manajemen kasus ditunjukkan pada gambar 8

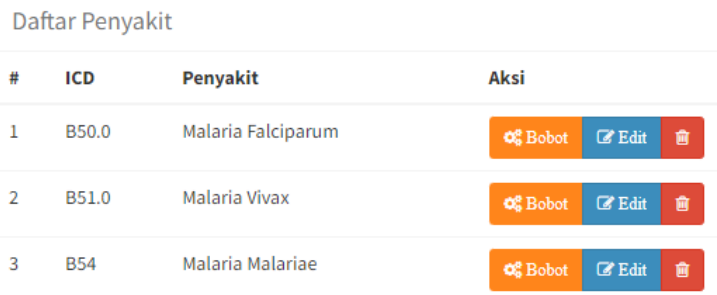

Gambar 8. Menu Daftar Penyakit

\section{Tampilan Basis Kasus}

Pakar dapat melakukan penambahan, perubahan, dan penghapusan data kasus yang ada pada tabel basis kasus melalui modul manajemen kasus seperti yang anda lihat pada gambar 9

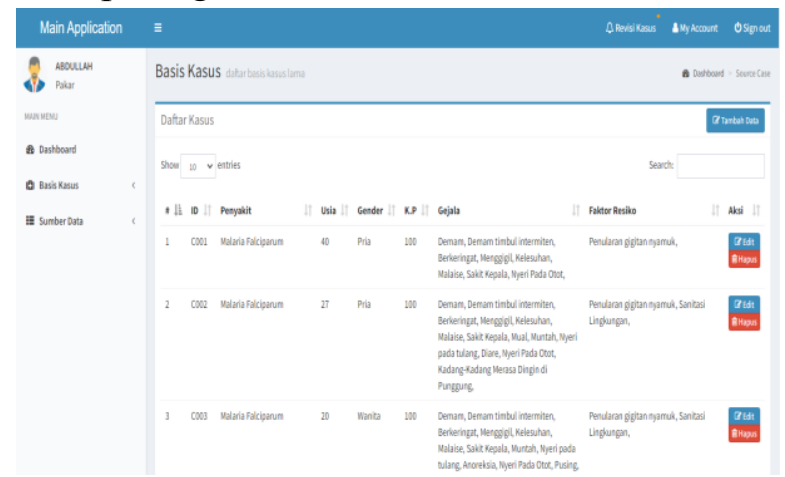

Gambar 9. Tampilan Basis Kasus

\section{Menu Hasil Diagnosis}

Diagnosis pasien dengan menginput data pasien (usia, jenis kelamin, gejala dan factor resiko) akan mendapatkan hasil diagnosis seperti pada gambar 10. Data tersebut bisa di simpan sebagai data kasus lama untuk menyelesaikan kasu-kasus baru. 


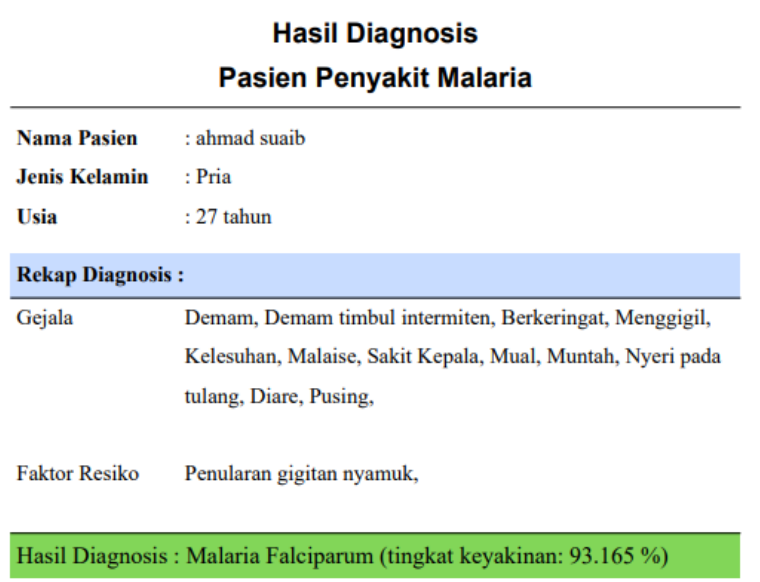

Senin, 29 November 202 Petugas Paramedis

Gambar 10 Hasil Diagnosis

\section{Hitung Akurasi}

Untuk mengetahui akurasi sistem maka kita lakukan pengimputan data testing dan akan membandingkan dengan data traning, apabila melebihi dari threshold (80\%) maka data tersebut di daignosis benar dan kurang dari threshold maka data tersebut salah.

Akurasi merupakan tingkat kedekatan pengukuran dengan menghitung banyak data yang benar dan salah. Pengujian akurasi sistem dilakukan dengan membandingkan jumlah diagnosis benar oleh sistem dengan jumlah data uji.

Untuk menghitung akurasi sistem menggunakan persaman 5 berikut:

Tabel 1 Konfusion Matriks Hasil Pengujian

\begin{tabular}{|c|c|c|c|c|}
\hline No & Jenis Penyakit & \multicolumn{3}{|c|}{ Hasil Diagnosis } \\
\cline { 3 - 5 } & & Benar & Salah & Jumlah \\
\hline 1 & $\begin{array}{c}\text { Malaria } \\
\text { Falsiparun }\end{array}$ & 9 & 1 & 10 \\
\hline 2 & Malaria Vivaks & 7 & 1 & 8 \\
\hline 3 & Malaria Malariae & 7 & 0 & 7 \\
\hline \multicolumn{4}{|c|}{ Total } \\
\hline
\end{tabular}

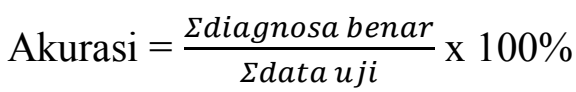

Akurasi $=\frac{25}{23} \times 100 \%=92 \%$

\section{KESIMPULAN}

Berdasarkan uraian pada bab sebelumnya dan setelah membuat pembahasan, implementasi penalarana berbasis kasus untuk sistem diagnosis penyakit malaria dengan menggunakan minkowski distance, maka dapat ditarik kesimpulan sebagai berikut:

1. Implementasi penalaran berbasis kasus untuk diagnosis penyakit malaria dengan menggunakan minkowski distance dapat dilakukan dengan baik

2. Sistem diagnosis penyakit malaria dengan Implementasi penalaran berbasis kasus menggunakan minkowski distance dapat memberikan hasil yang baik yakni dengan akurasi 92\% dan sesuai dengan yang diharapkan.

\section{Saran}

Penelitian ini diharapkan dapat dikembangkan menggunakan metode yang berbeda dan lebih baik sehingga hasil yang ditunjukkan oleh sistem dapat lebih akurat, serta data yang digunakan untuk membangun modelnya bisa diharapkan bisa lebih banyak lagi untuk memberikan tingkat akurasi yang lebih baik.

\section{DAFTAR PUSTAKA}

[1] BPS Kota Ternate (2019): Katalog Kota Ternate Dalam Angka 2019. BPS Kota Ternate.

[2] Pusdatin (2016): Info Datin, Malaria. Kemenkes RI, Jakarta

[3] M.Salmin., dan Hartati, S., 2019, CaseBased Reasoning untuk Diagnosis Penyakit Infeksi Saluran Pernapasan Akut, JIKO, Vol 2 No 1 2018, 21-26, Prodi Teknik Informatika, Universitas Khairun. 
[4] Pal, S. K. dan Shiu, S. C. K, 2004, Foundation of Soft Case-Based Reasoning, John Willey and Sons, Inc., Hoboken, New Jersey

[5] Mcleod, Jr. R. dan Schell, G., 2001, Management information System, 8ed, Prentice-Hall, New Jersey

[6] Jha, M.K., Pakhira, D., dan Chakraborty, B., 2013, Diabetes Detection and Care Applying CBR Techniques, IJSCE, 6, 2, 132-137.

[7] Mergio, J.M., dan Casanovas, M., 2008, The Induced Minkowski Ordered Weighted Averaging Distance Operator, ESTYLF08, Cuencas Mineras (Mieres-Langreo), Congreso Espanol sobre Tecnologiasy Logica Fuzzy, pp 35-41

[8] Nunez, H., Marre, M.S., Cortes, U., Comas, J., Martinez, M., Roda, I.R., dan Poch, M., 2004, A comparative study on the use of similarity measures in case based Reasoning to improve the classification of environmental system situations, Original Research Article, Environmental Modelling \& Software, Volume 19, Issue 9, pp 809-819. 